\title{
ワイドギャップ磁気軸受の開発とキャンドポンプ応用を考えた実験*
}

\author{
大塚靖 孝*1, 柿原功一*1, 栗田伸 幸*1 \\ 近藤良 ${ }^{* 2}$, 岡田養二*2
}

\section{Development and Canned Pump Application of Wide-Gap Magnetic Bearings}

\author{
Yasutaka OTUKA, Ko-ichi KAKIHARA, Nobuyuki KURITA, \\ Ryou KONDO and Yohji OKADA*3 \\ *3 Department of Mechanical Engineering, Ibaraki University, \\ 4-12-1 Nakanarusawa, Hitachi-shi, Ibaraki, 316-8511 Japan
}

\begin{abstract}
Maglev pump is widely requested for artificial heart or chemical industries. Hybrid magnetic bearing is recognized as high efficient one even with wide airgap and suitable for such applications. This paper proposes two types of hybrid magnetic bearings for canned maglev pump. One is the standard (STD) type and another is the internal permanent magnet (IPM) type. Both types are analyzed using the finite element package and designed. Then the experimental setups are made and their fundamental characteristics are explained. The results show stable levitation and promising characteristics for the practical use.
\end{abstract}

Key Words: Magnetic Bearing, Electromagnetic Actuator, Digital Control, Rotary Machinery

\section{1.は じめに}

遠心ポンプには通常接触型の軸受が用いられている が，半導体:製造等の超精密分野や特殊な薬液を用いる 応用では, 摺動部で生じる粉塵やせん断応力が問題と なる，そこで，軸を磁気吸引力により非接触支持する 磁気軸受を用いる磁気浮上ポンプが要望されている. しかし，ケミカルポンプ等においては，厚いポンプ内 壁を持つミ゙とから磁気的なギャップが広くなり，従来 の電磁石型磁気軸受では消費電力が大きくなる．その 問題に対して，永久磁石を併用するハイブリッド $(\mathrm{HB})$ 型は解決の可能性を持つ. HB 型では, 永久磁石によ り定常磁界を持たせることで, 従来の電磁石型磁気軸 受に比べ, 高効率な磁気軸受を構成することが可能で ある ${ }^{(1)}$.

高効率な磁気浮上ポンプ開発のため, 本研究では HB 型の二つの方式をワイドギャップ磁気軸受に適用 する.一つは一般的な構成のもので, 本研究ではス夕 ンダード (STD) 型と呼ぶ ${ }^{(2)}$ 。もう一方は, 永久磁石内 蔵(IPM) 型である ${ }^{(3),(4)}$. 二つの方式の模式図をそれぞ れ図 1 に示す. STD型では，二つのラジアル磁気軸受 間に永久磁石を配置し，図 1 の矢印線で表されるよう

\footnotetext{
* 原稿受付 2006 年 3 月 14 日.

*1 正員 茨城大学大学院理工学研究科( $316-8511$ 日立市中 成沢町 4-12-1).

$* 2$ 正員, 茨城大学工学部.

E-mail : y.okada@mx.ibaraki.ac.jp
}

なバイアス磁束を持ち，大きく磁気回路を構成する. 軸受間を磁性体で繋ぐ構造であることから重く大きな 構造となり，また軸受間の永久磁石から外部への磁束 の漏れが問題となる.

それらの問題を解決するために, IPM 型が提案され $た^{(3),(4)}$. IPM型では, 永久磁石をラジアル磁気軸受の 軸受面内に持ち, 軸受単体で磁気回路を構成すること から, 装置, ロータコアの小型軽量化が可能である. 更に, 全ての磁気回路がラジアル磁気軸受内で閉じる ことから，STD型のように軸受部以外での磁束の漏れ が生じるという問題は少ない. しかしながら，小さな 磁気回路を構成することから, 大きく磁気回路を構成 するSTD型と比較すると磁気回路内部で磁束がショー トしやすく，STD型の方が大きな軸受力が得やすいと 考えられる. ベアリングレスモータを使ったキャンド ポンプも開発されているが(5), 利用者から磁気浮上の 安定性が不足していると言った意見も聞かれている。

本稿では，まず STD 型, IPM 型それぞれの動作原 理を示し, 次にステータ形状決定のために行った磁界 解析の結果について述べる. そして設計, 製作された 実験装置について述べ，各種特性の測定結果を示す.

\section{2. ハイブリッド型の構造と動作原理}

本研究で扱う二つのハイブリッド型磁気軸受を紹介 する. 
(STD type)

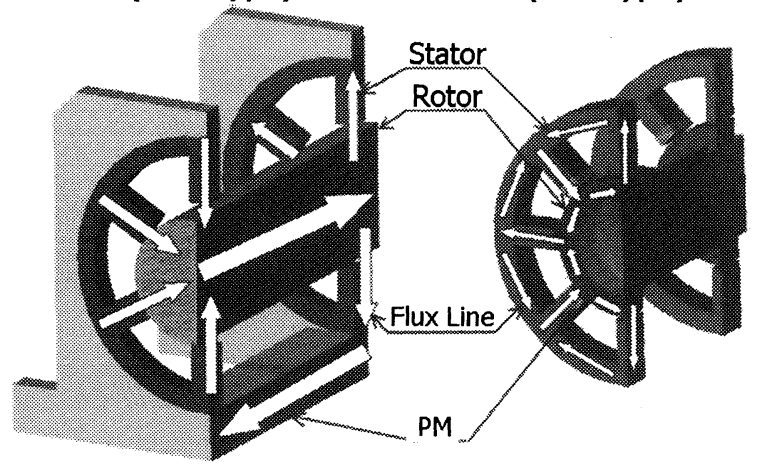

Fig. 1 Schematic of Two types HB Magnetic Bearings

\section{$2 \cdot 1$ スタンダード (STD) 型 STD 型磁気軸受の} 断面図を図 2 に示す. 図のような 6 突極の構造とし, 突極先端に磁極片を持つ構造とする.二つのラジアル 磁気軸受間に配置した永久磁石により，図 2 左のうす い太線のようなバイアス磁束が発生する。ロータの変 位に忘じ，ロータが遠ざかった側の極では，コイルに よる制御磁束とバイアス磁束とが強め合うように電流 を流し，近づいた側の極では，弱め合うようにして電 流を流す。図 2 左では上側の磁束を強め，下側を弱め, 上下の磁気吸引力の差からロータに上向きの力を発生 させ，ラジアル 2 方向を能動的に制御する。

アキシャル方向はラジアル磁気軸受の吸引力により 受動安定であるが，その減衰力は小さい. ポンプのよ うにアキシャル方向力を受ける装置での安定性を考え, STD 型のアキシャル方向制御が開発されている(2). 動 作原理を図 2 右に示す，ステータコアの幅をロータコ アよりも広めることで，磁束を斜めに通し，吸引力に 軸方向成分を持たせる.アキシャルコイルはステータ 内周の溝に配置される. アキシャルコイルによる制御 磁束は図 2 右の矢印円で示す. 図 2 右でバイアス磁束 と制御磁束とを左側では強め合い，右側では弱め合い， 左右の磁気吸引力の差からロータに左向きの力を発生 させている.このようにしてアキシャル方向の制御を 行う. 突極の先端を広げているのは, アキシャルコイ ル全周から制御力を得るためである。

2.2 永久磁石内蔵 (IPM) 型図 3 に IPM 型磁気 軸受の断面図を示す.90 度毎にコイルを巻いた主極 を持ち, その中間方向 (45 度方向) に永久磁石を配置 した補極を持たせた計 8 極の構成をとる. 補極に配置 された永久磁石により, 図 3 左のようなバイアス磁束 を生じる. STD 型と同様に，ロータの变位に応じて制 御電流を流してバイアス磁束と制御磁束とが強め合う 極と弱め合う極が生じるようにする. 図 3 左では, 上

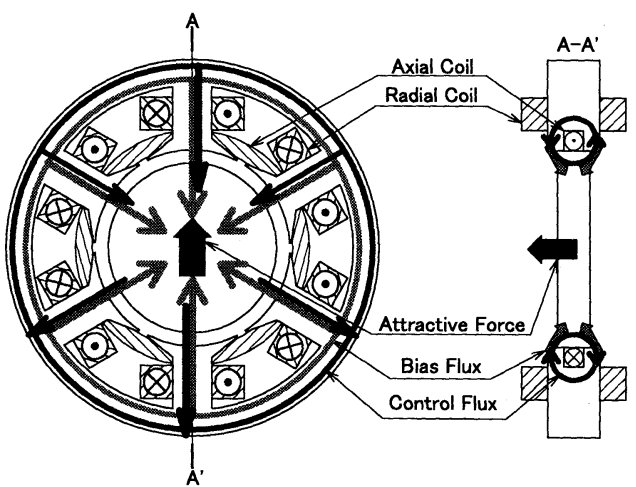

Fig. 2 Principle of STD type HB Magnetic Bearing

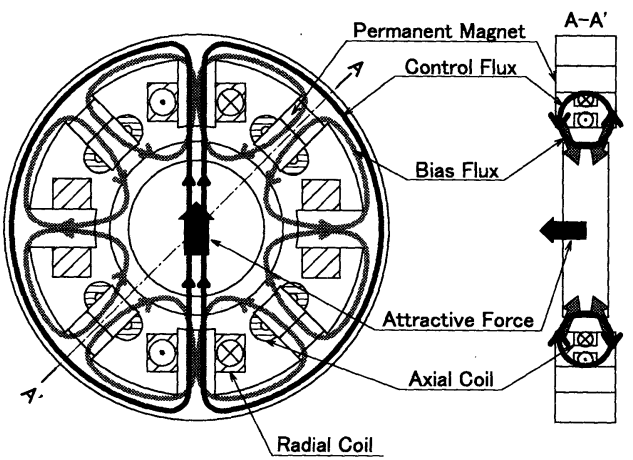

Fig. 3 Principle of IPM type HB Magnetic Bearing

側の磁束を強め，下側を弱め，上向きの吸引力を発生 させている.このようにしてラジアル 2 方向の制御を 行う.

IPM 型においてもアキシャル方向の安定性のため, 受動安定に加えて制御を行う必要がある.そこで IPM 型のアキシャル方向制御が提案されている. 図 3 右に IPM 型磁気軸受の補極断面を示す.IPM 型において も，ステータコアの幅をロータコアよりも広めること で，吸引力に軸方向成分を持たせる．アキシャルコイ ルは，補極先端に配置した $\mathrm{H}$ 型コアに巻く．アキシャ ルコイルによる制御磁束は図 3 右の矢印円で示されて いる. バイアス磁束と制御磁束から左右で磁気吸引力 の差を生じさせ, 図3右ではロータに左向きの力を生 じさせている.このようにしてアキシャル方向の制御 を行う。

\section{3. 磁場解析による設計}

二つの方式それぞれについてステータ形状最適化の ため，有限要素解析ソフト”ANSYS”を用いた磁場解 析を行った.

3.1 IPM 型図 4 にIPM 型磁気軸受の 2 次元解 析モデルを示す. 形状は開発予定ポンプに合わせたロー 

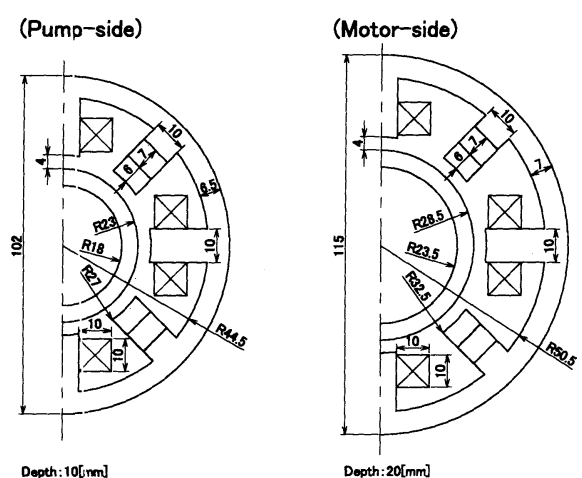

Fig. 4 Schematic of 2D Analytical Model (IPM type)

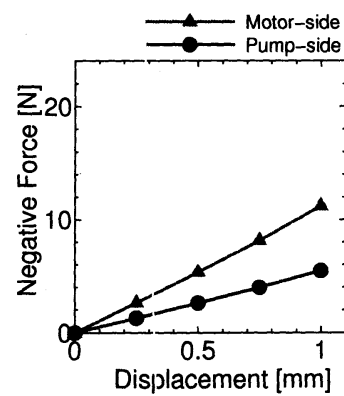

Fig. 5 Neggative Force

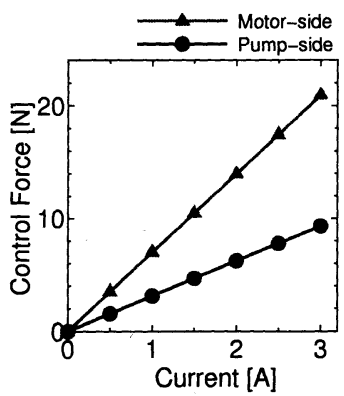

Fig. 6 Control Force
タ・ステータ経を選定した. 最大軸受力を考え, モータ 側磁気軸受の幅は $20[\mathrm{~mm}]$, ポンプ側では $10[\mathrm{~mm}]$ と し，エアギャップ $4[\mathrm{~mm}]$, 永久磁石はNEOMAX-38H, ラジアルコイル 240 [turns/pole] とした. 負ばね力と制 御力の計算結果を図 5 , 図6にそれぞれ示す. $1.5[\mathrm{~mm}]$ の隔壁のため可動範囲は $\pm 1[\mathrm{~mm}]$ 以内であり, 図 5, 図 6 より制御力の計算值は負ばね力と比較して充分大 きな値であると考えられる.これらの結果より, 解析 モデルの形状をもとに実験装置を設計, 製作する.

3.2STD 型図 7 にSTD 型磁気軸受の解析モ デルを示す. 永久磁石は 120 度毎に 3 個所配置され ている. IPM 型と同様, モー夕側磁気軸受の幅は 20 $[\mathrm{mm}]$, ポンプ側では $10[\mathrm{~mm}]$ とし, エアギャップ 4 $[\mathrm{mm}]$, 永久傢石は NEOMAX-38H, ラジアルコイル 240 [turns/pole] とした. STD 型は力が大きいことが予 想されるため, ポンプを保守が容易なオーバハングで 設計する. ST:D型では 2 次元解析により形状を図 7.の ように決定し，そのモデルについて 3 次元解析を行っ た.ラジアル方向の制御力の計算結果を図 8(PM:3)に 示す. 図 8 より 3 [A] の制御電流に対して $17.5[\mathrm{~N}]$ の 制御力が得られたが，ロータの推定重量は約 $1[\mathrm{~kg}]$ で あり，不十分な力特性と考えられる.ここでエアギャッ
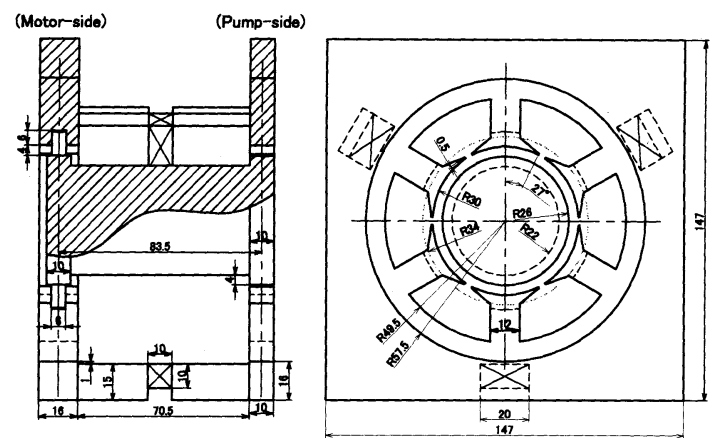

Fig. 7 Schematic of 3D Analytical Model (STD type)

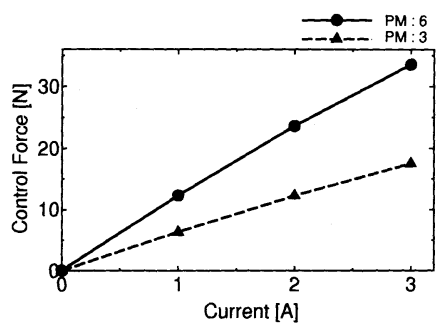

Fig. 8 Control Force versus Current (Radial dir.)

プ中の磁束密度が約 0.05 [T] と低いことから, バイア 不磁束が不足と考え, 磁石数を増やすこととした. こ の解析では, 磁石の保磁力を倍にすることで仮想的に 磁石数を倍とする. 磁石数 6 の場合では, エアギャッ プ中の磁束密度が約 0.1 [T] であり, 制御電流 3 [A] で 約 $34[\mathrm{~N}]$ の制御力が得られ，充分な力特性が得られた と考える.この解析結果をもとに実験装置を設計した.

\section{IPM 型の浮上·回転実験}

4.1 実験装置 磁場解析の結果より設計した IPM 型の実験装置を図 9 に示す. IPM型ではラジアル方向 制御のみを行い, アキシャル方向は受動安定とした. モータの回転をロータへ非接触に伝達させるために磁 気カップリングを用いる. ロータ重量は $0.625[\mathrm{~kg}]$ と なった.コントローラには DSP(dSPACE, DS1104)に よるディジタル PID 制御を用いる. 変位センサには渦 電流式センサ (電子応用 PU-07, 感度 $3.3[\mathrm{~V} / \mathrm{mm}]$ ) を用 いる. センサはロータとステータに $1.5[\mathrm{~mm}]$ の隔壁が あることと設置スペースを考え， ギャップ 2〜4 [mm] を検出する. 従って, センサ出力上限は約 13.2 [V] と なる.しかし $\mathrm{dSPACE}$ の A/D コンバータの検出電圧 上限は 10 [V] であるため, センサ感度を本来の約半 分である $1.6[\mathrm{~V} / \mathrm{mm}]$ に落としている. パワーオペア ンプ(PA12)を用いて構成された $-1[\mathrm{~A} / \mathrm{V}]$ の増幅度を 

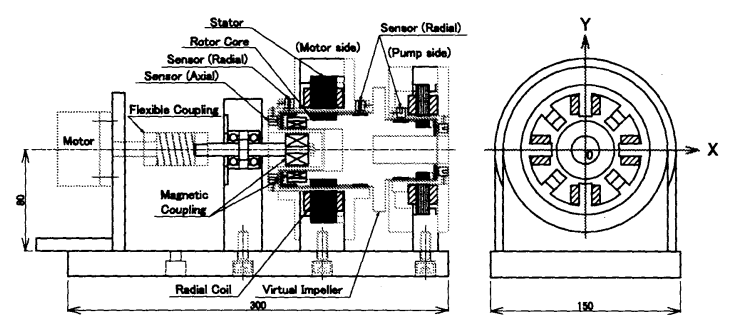

Fig. 9 Schematic of Experimental Setup (IPM type)
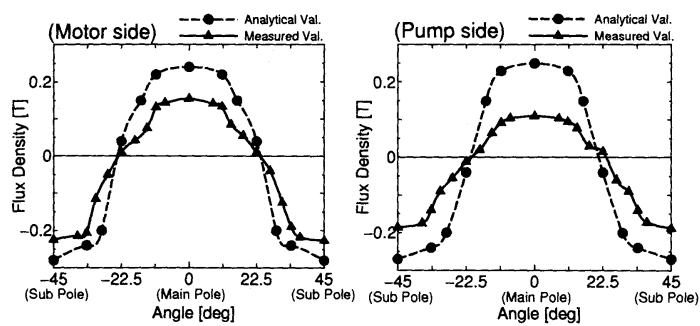

Fig. 10 Flux Density Distribution

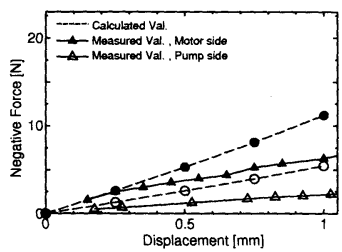

Fig. 11 Negative Force

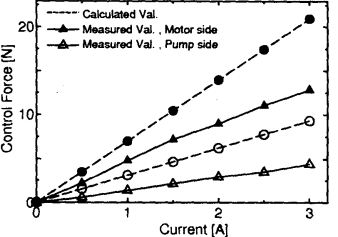

Fig. 12 Control Force
持つ駆動アンプを使用する，供給電圧 $\pm 24[\mathrm{~V}]$, 電流 制限は $3[\mathrm{~A}]$ とした.

$4 \cdot 2$ 静特性磁束密度, 負ばね力, 制御力の測 定結果と解析値との比較をそれぞれ図 10〜図 12 に示 す. 図 10 より主極部において測定値が解析値の約 5 割程の值である.これは磁場解析は二次元近似解析で あり，考慮されなかった 3 次元的な磁束の漏れによる 影響が主であると考えられる.同様に図 11, 図 12 に おいて解析値と測定值のずれが見られるが，バイアス 磁束の低さが主な原因と考えられる. しかし, 隔壁内 の可動範囲では制御力が負ばね力を上回り, 浮上制御 が可能であることがわかる. 制御力係数はモー夕側軸 受で約 4.3 [N/A], ポンプ側で約 1.5 [N/A] となった.

$4 \cdot 3$ 動特性軸受の浮上試験を行った. 軸受制 御には集中 PID 制御を適用した. 制御系の構成を図 13 に示す．まず，センサによって検出された変位信号 からロータ重心における並進量と傾き量を計算する. そこから PID によって並進と傾きを制御する力, ト ルクを算出し，それらを軸受それぞれの力へと変換す る. それらを制御力係数で割り, 制御電流值を算出し, パワーアンプを介して制御コイルへ電流を供給する.

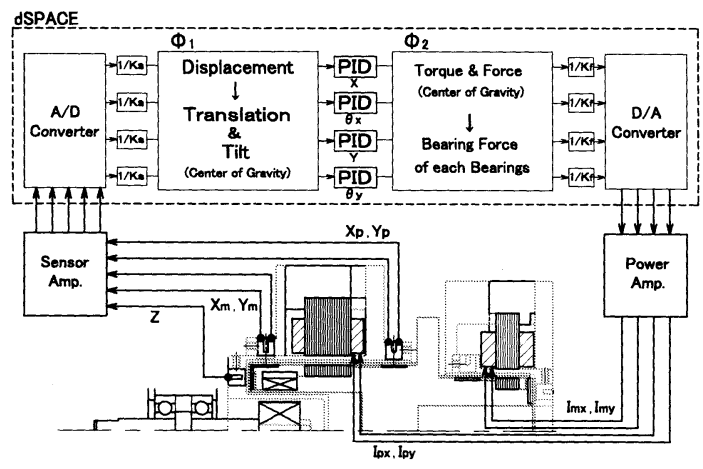

Fig. 13 Schematic of Centralized Control System

Table 1 Control Gains (IPM type)

\begin{tabular}{|ll||c|c|}
\hline \multicolumn{1}{|c|}{ Translation } & x-dir. & y-dir. \\
\hline \hline $\mathrm{K}_{P}$ & {$[\mathrm{~N} / \mathrm{mm}]$} & 100 & 150 \\
\hline $\mathrm{K}_{I}$ & {$[\mathrm{~N} / \mathrm{sec} \cdot \mathrm{mm}]$} & 500 & 500 \\
\hline $\mathrm{K}_{D}$ & {$[\mathrm{~N} \cdot \mathrm{sec} / \mathrm{mm}]$} & 0.25 & 0.25 \\
\hline \hline & Tilt & x-dir. & y-dir. \\
\hline \hline $\mathrm{K}_{P}$ & {$[\mathrm{~N} \cdot \mathrm{m} / \mathrm{rad}]$} & 80000 & 80000 \\
\hline $\mathrm{K}_{I}$ & {$[\mathrm{~N} \cdot \mathrm{m} / \mathrm{sec} \cdot \mathrm{rad}]$} & 5000 & 5000 \\
\hline $\mathrm{K}_{D}$ & {$[\mathrm{~N} \cdot \mathrm{m} \cdot \mathrm{sec} / \mathrm{rad}]$} & 250 & 250 \\
\hline
\end{tabular}

並進，傾きそれぞれのゲインは実験的に設定し，表 1 の值に決定した. またサンプリング時間 $\tau=0.1[\mathrm{~ms}]$, 微分時定数 $T_{D}=0.3[\mathrm{~ms}]$ とした.

基本的な浮上特性を確認するため, まず周波数応答 を測定した. 浮上制御した状態で，センサ入力にFFT アナライザから外乱信号として $\pm 0.03[\mathrm{~mm}]$ 変位相当 の正弦波信号を加え, そのときのセンサ出力と入力外 乱からゲインと位相を測定した。 モータ側, ポンプ側 の測定結果をそれぞれ図 14, 図 15 に示す.モー夕側 では約 $40[\mathrm{~Hz}]$ で, ポンプ側では約 $70[\mathrm{~Hz}]$ に共振が あり，ピークグインは 4〜 $5[\mathrm{~dB}]$ に抑えられ，良好な 特性であると考えられる.

4.4 浮上回転特性 浮上回転特性を確認するた めアンバランス応答を測定した. ロータが定常回転時 の一定時間内におけるロータの振動振幅の最大-最小 值を測定した. モ一タ側, ポンプ側の測定結果をそれ ぞれ図 16, 図 17 に示す.モータ側では磁気カップリ ングから振動を受けるため, 振幅が $0.4[\mathrm{~mm}]$ 以上と 大きくなる. またアキシャル方向ではタッチダウンが 生じた. そのため, 軸受力の向上, アキシャル方向制 御の付加, 等の改良が必要である.

改良の方法としては、軸受厚みを増やし 3 次元的な 漏れを少なくして力を大きくすることと, 磁石を増や して磁束密度を増す実験を進めている．また IPM 型 のアキシャル磁気軸受の開発研究も進めている. 


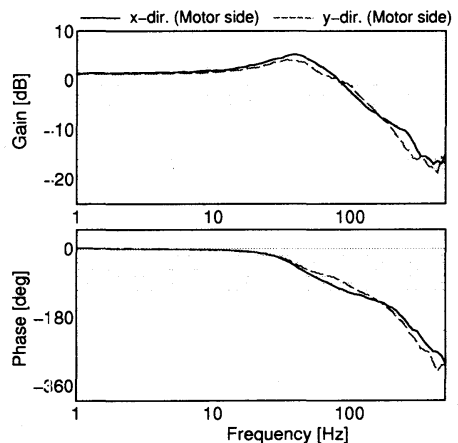

Fig. 14 Frequency Response (Motor side)

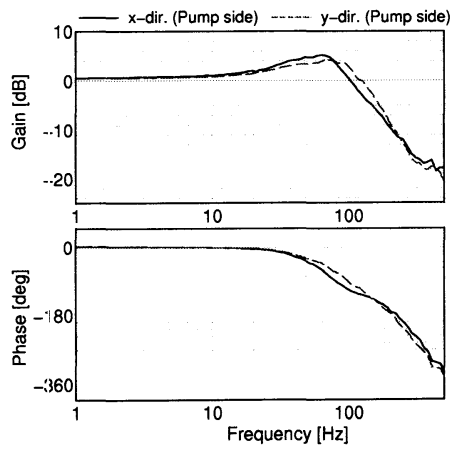

Fig. 15 Frequency Response (Pump side)

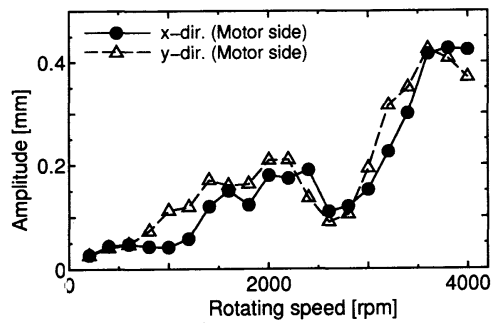

Fig. 16 Unbalance Response (Motor side)

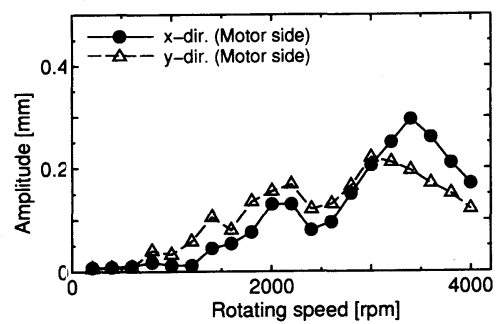

Fig. 17 Unbalance Response (Pump side)

\section{STD 型の浮上 - 回転実験}

$5 \cdot 1$ 実䮖装置 STD 型の実験装置を図 18 に示 す. 本装置では解析モデルから更にバイアス磁束を

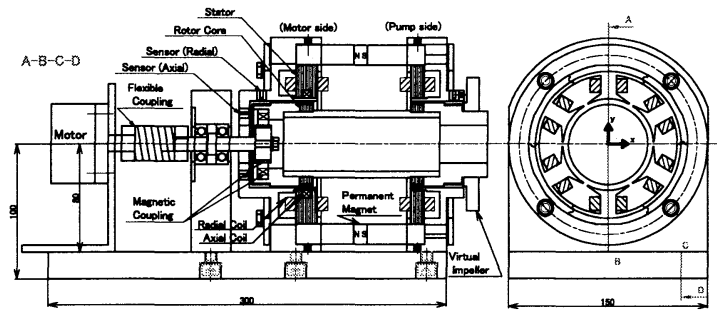

Fig. 18 Schematic of Experimental Setup (STD type)

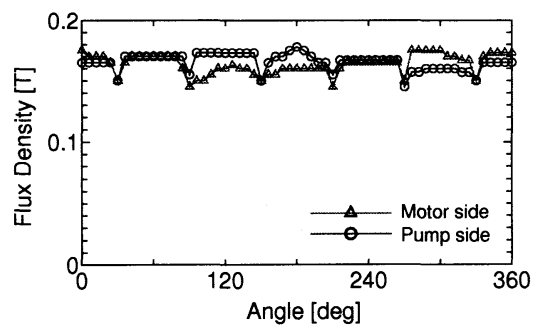

Fig. 19 Flux Density Distribution

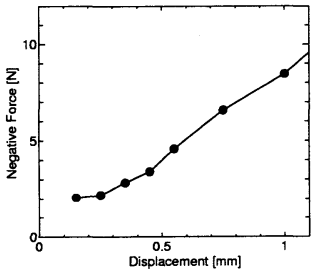

Fig. 20 Negative Force
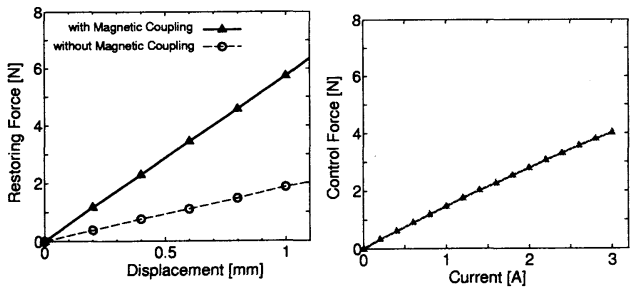

Fig. 22 Restoring Force Fig. 23 Control Force

強めるため，磁石の大きさを $10 \times 10 \times 20[\mathrm{~mm}]$ から $15 \times 10 \times 20[\mathrm{~mm}]$ に変更し, また磁性材を磁気特性の 良いものに変更している. 永久磁石数は 6 個とした. センサ, アンプ, DSPはIPM 型と同じものを使った. アキシャル制御コイルはモータ側軸受に配置され，巻 数 80 [turns] とした. ロータ重量は $0.967[\mathrm{~kg}]$ となった.

5.2 静特性 エアギャップの磁束密度, ラジアル 方向の負ばね力，制御力の測定結果をそれぞれ図 19 〜図 21 に示す. 図 20, 図 21 の結果はモータ側, ポン プ側軸受の力を個別に測定できなかったため, その合 力を示している. 図 19 よりモータ側, ポンプ側それ 


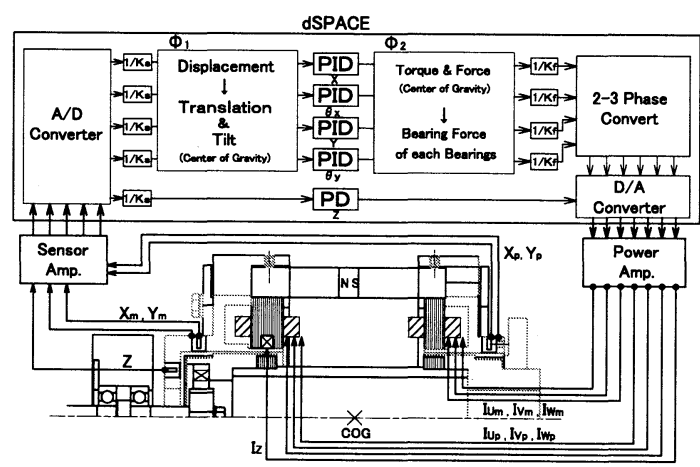

Fig. 24 Schematic of Centralized Control System

Table 2 Control Gains (Centralized PID)

\begin{tabular}{|c|c|c|}
\hline & Translation & x,y-dir. \\
\hline $\mathrm{K}_{P}$ & {$[\mathrm{~N} / \mathrm{mm}]$} & 200 \\
\hline $\mathrm{K}_{I}$ & {$[\mathrm{~N} / \mathrm{sec} \cdot \mathrm{mm}]$} & 3000 \\
\hline $\mathrm{K}_{D}$ & [N. sec/mm] & 0.5 \\
\hline & Tilt & $\mathrm{x}, \mathrm{y}$-dir. \\
\hline $\mathrm{K}_{P}$ & {$[\mathrm{~N} \cdot \mathrm{m} / \mathrm{rad}]$} & $4 \times 10^{5}$ \\
\hline $\mathrm{K}_{I}$ & {$[\mathrm{~N} \cdot \mathrm{m} / \mathrm{sec} \cdot \mathrm{rad}]$} & $5 \times 10^{5}$ \\
\hline $\mathrm{K}_{D}$ & {$[\mathrm{~N} \cdot \mathrm{m} \cdot \mathrm{sec} / \mathrm{rad}]$} & 1500 \\
\hline \multicolumn{3}{|c|}{ Axial dir. } \\
\hline $\mathrm{K}_{P}$ & {$[\mathrm{~A} / \mathrm{mm}]$} & 4 \\
\hline $\mathrm{K}_{D}$ & [A. sec/mm] & 0.04 \\
\hline
\end{tabular}

れ全周にわたり約 0.17 [T] の磁束密度が得られた．磁 石を大きくしたため, 解析より約 1.7 倍の磁束密度を 得ている. 図 20, 図 21 より IPM 型と比較して大きな 軸受力が得られ, 良好な浮上特性が期待できる. 負ば ね力係数は約 $8.1[\mathrm{~N} / \mathrm{mm}]$, 制御力係数は約 20.5 [N/A] であった。

アキシャル方向の受動復元力と制御力の測定結果を 図 22, 23 に示す. 図 22 には磁気カップリングの有無 それぞれの結果を示す. 強力な磁気カップリングを用 いたことで復元力係数が約 5.7 [N/mm], また制御力係 数は約 1.3 [N/A] となり充分な值が得られた.

$5 \cdot 3$ 動特性軸受制御には集中 PID 制御を適用 した. 制御系の構成を図 24 に示す. 制御の流れはIPM 型と概ね同じであるが，STD型は6突極であることか ら，x，y 方向の制御電流值として算出されたものを 2 相 3 相変換している. またアキシャル方向は受動安定 であることから，制御にはディジタル PD 制御を用い た. 制御ゲインは実験的に決定し，表 2 の值とした. モータ側, ポンプ側軸受の周波数応答の測定結果をそ れぞれ図 25, 図 26 に示す. IPM 型と同様に, 浮上制 御状態で FFT アナライザーから外乱信号を入れ，その ときの変位応答を求めている. それぞれ約 $80[\mathrm{~Hz}]$ に

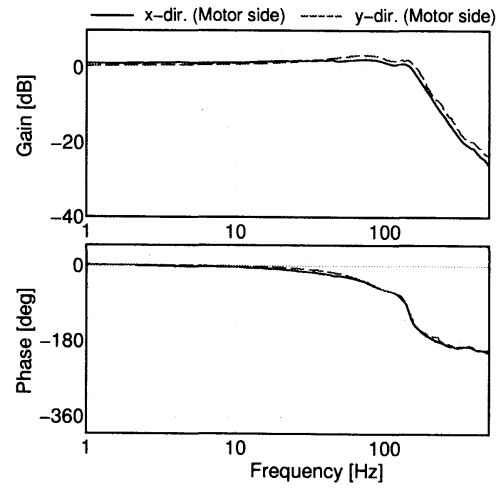

Fig. 25 Frequency Response (Motor side)

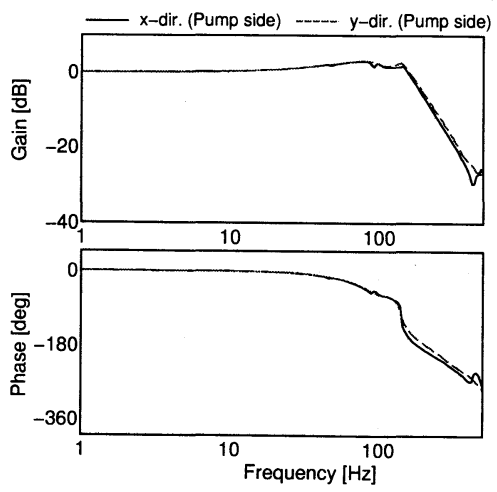

Fig. 26 Frequency Response (Pump side)

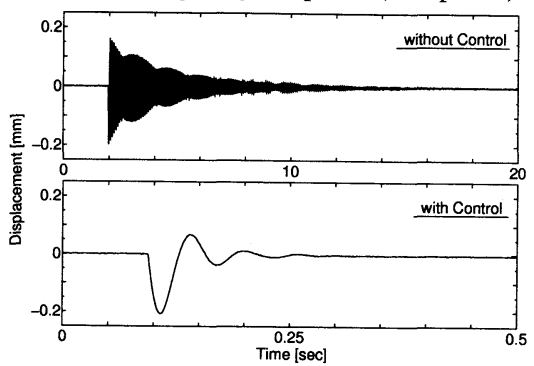

Fig. 27 Impulse Rersponse (Axial dir.)

共振があり，ピークゲインは約 $3[\mathrm{~dB}]$ に抑えられた. アキシャル方向のインパルス応答測定結果を図 27 に 示す. 図 27 上の無制御時の結果では振動の収束に約 10 [sec] 要したが, 同図下の制御時では約 0.2 [sec] で 収束した．ラジアル方向，アキシャル方向ともに，良 好な制御結果が得られている.

5.4 浮上回転特性 アンバランス応答の測定結 果を図 28，29に示す．モータの回転限界の 4000 [rpm] まで振動振幅が $0.1[\mathrm{~mm}]$ 以下に抑えられ, 安定した浮 上回転が確認された．アキシャル方向は最大でも 0.05 [mm] 以下であり，3 軸とも安定な浮上回転に成功した. 


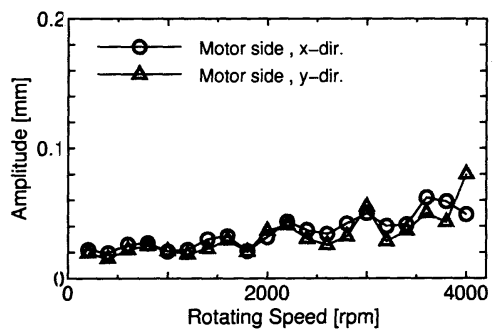

Fig. 28 Unbalance Response (Motor side)

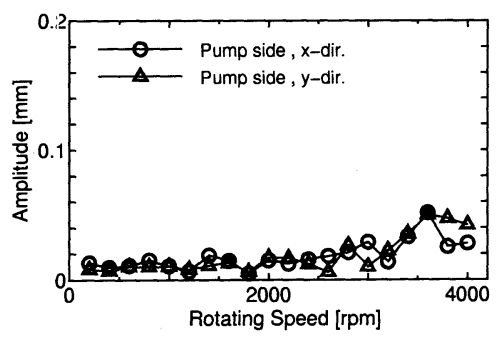

Fig. 29 Unbalance Response (Pump side)

$$
\text { おわりに }
$$

高効率の磁気浮上ポンプ開発のため，STD 型およ び，IPM型の 2 つの方式をワイドギャップ磁気軸受に 適用した. それぞれ磁場解析を行い，実験装置を設計・ 製作し，基本特性の測定を行ったＩPM型装置では良 い動特性方得られたが，浮上回転特性は不十分であり， 軸受力の向上が必要である. しかし小型で安価なキャ ンドポンプには, 適した方式と考えられる. STD型で は充分な䩜受力を持ち, 浮上回転試験においても良い 特性が得られ, 磁気浮上ポンプヘの良い適用性を示す ことができた. 今後は，IPM 型装置の改良を行いその 性能を確認し，またそれぞれの方式に適応した磁気浮 上ポンプを製作・試験を行い，回転による影響や流体 力の影響を検討し，その有用性を確認する予定である.

\section{文献}

(1) Y. Okada, et. : Fundamental and Application of Magnetic Bearings, JSME New Technology Series, Yokendo, (1995)

(2) N. Kurita, et. , Transactions of the Japan Society of Mechanical Engineers, Series C, Vol. 70, No. 694, (2004), pp. $1560-1565$

(3) K. Kakihara, H. Koyanagi, and Y. Okada : Transactions of the Japan Society of Mechanical Engineers, Series C, Vol. 71, No. 710, (2005), pp. 2968-2974

(4) M. Reisinger, et. : CD-ROM Proc. of Ninth Int. Symp. on Magnetic Bearings, Lexington, KY, USA, Aug. 3-6, (2004), pp. 1-6

(5) M. Neff, N. Barletta, and R. Schöb : Proc. of Eigth Int. Symp. on Magnetic Bearings, Mito, Japan, Aug. 26-28, (2002), pp. 283-288 